\title{
Gallium Ga 68 DOTA-JR11
}

National Cancer Institute

\section{Source}

National Cancer Institute. Gallium Ga 68 DOTA-JR11. NCI Thesaurus. Code C124930.

A radioconjug ate consisting of the somatostatin antagonistic peptide JR11 that is linked, via the chelating agent dodecanetetraacetic acid (DOTA), to the beta-emitting radioisotope gallium $\mathrm{Ga} 68$, with potential imaging activity during positron emission topography/computed tomography (PET/CT). Upon administration, gallium Ga 68DOTA-JR11 binds to somatostatin receptors (SSTRs), with high affinity for SSTR2, present on the cell membranes of many types of neuroendocrine tumor (NET) cells. Upon binding and internalization, this radioconjugate can be used to quantify tumor uptake of JR11 using PET/CT. SST Rs have been shown to be present in large numbers on NETs and their metastases, while most normal tissues express low levels of SSTRs. 